\title{
Pemberian Ekstrak Bayam Merah (Amarantus Tricolor linn) Memperbaiki Ekspresi BDNF dan GLUR1 pada Area Hipokampus Tikus Muda yang Terpapar Anestesi Inhalasi Halothane dan Sevoflurane
}

\author{
Raden Argarini, ${ }^{1}$ Kristanti Wanito Wigati, ${ }^{1}$ Lilik Herawati, ${ }^{1}$ Wibi Riawan, ${ }^{2}$ Nancy M. Rehatta ${ }^{3}$ \\ ${ }^{1}$ Departemen Fisiologi Fakultas Kedokteran Universitas Airlangga Surabaya, ${ }^{2}$ Laboratorium Biokimia \\ Biomolekuler Fakultas Kedokteran Universitas Brawijaya Malang, ${ }^{3}$ Departemen Anestesiologi dan Reanimasi \\ Fakultas Kedokteran Universitas Airlangga Surabaya
}

\begin{abstract}
Abstrak
Otak dalam tahap perkembangan memiliki tingkat kerentanan lebih tinggi terhadap zat anestesi dibanding dengan otak orang dewasa. Penelitian ini bertujuan mengamati pengaruh pemberian ekstrak bayam merah terhadap penanda biologis fungsi kognitif dan neuroplastisitas, yaitu brain derived neurotrophic factor (BDNF) dan AMPA glutamate receptor subunit 1 (Glur1) pada area hipokampus tikus yang terpapar anestesi inhalasi halothane dan sevoflurane. Rancangan penelitian adalah randomized posttest only control group. Penelitian ini dilakukan di Departemen Biokimia Fakultas Kedokteran Universitas Airlangga dan prosedur anestesi dilakukan di Rumah Sakit Hewan Fakultas Kedokteran Hewan Universitas Airlangga pada bulan Mei-Oktober 2014. Subjek penelitian adalah 23 ekor tikus putih jantan (Rattus norvegicus) galur Wistar, umur 1-1,5 bulan, bobot kurang lebih 60-100 gram dengan kondisi sehat fisik. Subjek dibagi menjadi 5 kelompok, yaitu K (kontrol); K1 (halothane 1 MAC); K2 (bayam merah $800 \mathrm{mg} / \mathrm{kgBB}+$ Halothane $1 \mathrm{MAC}$ ); K3 (sevoflurane 1MAC) dan K4 (bayam merah $800 \mathrm{mg} / \mathrm{kgBB}+$ sevoflurane $1 \mathrm{MAC}$ ). Hasil penelitian menunjukkan penurunan ekspresi BDNF pada pemberian halothane dan sevoflurane serta peningkatan kembali ke normal pada kelompok yang sebelumnya telah diberikan bayam merah sebelum terpapar gas anastesi $(\mathrm{p}=0,000)$. Ekspresi GLUR1 meningkat pada pemberian halothane dan sevoflurane dan penurunan kembali ke normal pada kelompok yang sebelumnya telah diberikan bayam merah sebelum terpapar gas anastesi $(\mathrm{p}=0,000)$. Simpulan penelitian ini adalah pemberian ekstrak bayam merah memiliki potensi untuk mencegah neurotoksisitas pada fungsi kognitif tikus yang terpapar gas anastesi. [MKB. 2016;48(3):148-54]
\end{abstract}

Kata kunci: AMPA Glutamate Receptor subunit 1 (GLUR1), Brain Derived Neurotrophic Factor (BDNF), ekstrak bayam merah, halothane, sevoflurane

\section{Red Spinach Extract Administration (Amarantus Tricolor linn) in Young Rats Exposed to Inhalation Anesthetic Halothane and Sevoflurane Improves BDNF and GLUR1 Expressions in Hippocampus Area}

\begin{abstract}
In the development stage, brain has a higher level of vulnerability than the adult brain to anesthetic agents. The aim of this study was to investigate the effects of red amaranth extract to brain derived neurotrophic factor (BDNF) and AMPA glutamate receptor subunit 1 (Glur1) expressions as biomarkers of cognitive and neuroplasticity in rat hippocampus areas exposed to inhaled anesthetics halothane and sevoflurane. The design of this study was a randomized posttest only control group. This study was conducted at the Department of Biochemistry Faculty of Medicine, Universitas Airlangga, and the anesthetic procedures were performed at the Veterinary Hospital, Faculty of Veterinary Medicine Universitas Airlangga during the period of May-October 2014. The subjects of this study were 23 white male rats (Rattus norvegicus) wistar strain, aged 1-1.5 months, weighted approximately 60-100 grams in a healthy physical condition. The subjects were divided into 5 groups, K (control); K1 (1 MAC halothane); K2 (red amaranth $800 \mathrm{mg} / \mathrm{kgBW}+1 \mathrm{MAC}$ halothane); K3 (1 MAC sevoflurane); and K4 (red amaranth $800 \mathrm{mg} / \mathrm{kgBW}+1 \mathrm{MAC}$ sevoflurane). The results of this study showed a decrease in the expression of BDNF when halothane and sevoflurane were administered. Red amaranth treatment prior to anesthetic gases exposure preserved and increased BDNF expression $(\mathrm{p}=0.000)$ while GLUR1 expression increased in the group that received halothane and sevoflurane administration and decreased back to normal in the group that received red amaranth treatment prior to exposure to anesthetic gases $(\mathrm{p}=0.000)$. In conclusion, red amaranth extract has the potential effect to prevent cognitive neurotoxicity on the cognitive function in rats exposed to anesthetic gases. [MKB. 2016;48(3):148-54]
\end{abstract}

Key words: AMPA glutamate receptor subunit 1 (GLUR1), brain derived neurotrophic factor(BDNF), halothane, sevoflurane, red amaranth extract

Korespondensi: Raden Argarini, dr., M.Kes, Departemen Fisiologi Fakultas Kedokteran Universitas Airlangga Surabaya, Jalan. Prof. Dr. Moestopo No.47 Surabaya 61256, mobile 08562163745, e-mail raden-a@fkg.unair.ac.id 


\section{Pendahuluan}

Hampir semua tindakan pembedahan dilakukan di bawah pengaruh anestesi dan sering kali dilakukan memakai anestesi umum. Anestesi umum adalah suatu keadaan reversibel yang mengubah status fisiologis tubuh, dan ditandai dengan kehilangan kesadaran (sedasi), persepsi nyeri (analgesi), memori (amnesi), serta relaksasi. ${ }^{1}$ Penelitian mengenai bahaya anestesi yang dilakukan menggunakan data 2.600 anak yang lahir di Australia antara tahun 1989 dan 1992, sebanyak 321 anak mendapatkan anestesi setidaknya satu kali sebelum mereka berusia tiga tahun. Di usia 10 tahun, seluruh responden tersebut dilakukan tes untuk dapat mengukur kemampuan berpikir, bahasa, serta keterampilan motorik dan juga perilaku. Hasilnya tidak ada perbedaan pada gangguan perilaku atau fungsi motorik berdasarkan pernah tidaknya mereka mendapat anestesi di usia bayi atau balita. Meski begitu, anak yang mendapat anestesi dua kali, menunjukkan gejala kesulitan berbahasa dan sekitar 70\% memiliki masalah dalam penalaran dibanding dengan kelompok nonanestesi. Para peneliti mengelompokkan "kesulitan berbahasa" sebagai di bawah standar nilai. Anak dan bayi yang mendapatkan anestesi atau pembiusan untuk operasi berisiko mengalami gangguan kemampuan berkomunikasi. Pada penelitian ternyata gangguan itu tampak di usia 10 tahun. Kendati begitu, belum dapat dipastikan apakah penyebabnya adalah prosedur anestesi. Sampai dengan saat ini belum ada penelitian prospektif mengenai efek paparan halothane dan sevoflurane pada masa anak-anak terhadap struktur neuron dan neurokognitif. Namun, sudah dilaporkan terdapat abnormalitas perilaku yang bersifat sementara seperti ketakutan terhadap orang asing, pemarah, mencari perhatian, kesulitan tidur, dan juga kecemasan setelah terpapar gas anestesi halothane. Sevoflurane menyebabkan abnormalitas pada EEG dan bangkitan terutama jika prosedur anestesi dilakukan tanpa sedasi preoperasi dan juga pengaturan ventilasi serta perubahan perilaku seperti pemarah, gangguan tidur dan hilangnya nafsu makan. ${ }^{2}$

Otak dalam tahap perkembangan memiliki beberapa perbedaan yang nyata dari pada otak orang dewasa yang memberikan dasar fisiologis peningkatan kerentanan terhadap zat anestesi. ${ }^{3}$ Pada otak dalam tahap perkembangan, reseptor zat hantar saraf $\delta$-aminobutyric acid (GABA) dan glutamat dengan tipe yang berbeda harus diekspresikan pada keadaan tertentu untuk menghasilkan struktur dan fungsi otak normal. ${ }^{4}$
Anestesi umum memiliki target terutama pada beberapa kanal ion bergantung pada zat hantar sarafnya serta beberapa sistem sinyal sel yang meliputi kanal ion-terikat ligan yang bersifat inhibisi terutama reseptor $\delta$-Aminobutyric acid (GABA), glisin, dan yang bersifat eksitasi seperti reseptor glutamat tipe $\mathrm{N}$-methyl $\mathrm{D}$-aspartate (NMDA) serta AMPA pada celah sinaps dan ekstrasinaps; kanal ion tersebut yang mengatur eksitabilitas dan transmisi kimia seperti kanal $\mathrm{Na}$, Ca dan $\mathrm{K}$, serta jalur sinyal interseluler pleitotropik sehingga anestesi umum juga mempunyai efek nonanestesi yang bervariasi mulai dari yang menguntungkan hingga yang merugikan. ${ }^{3}$

Sevoflurane dan halothane merupakan dua jenis obat anestesi inhalasi yang sering digunakan sebagai maintenance anestesi umum selama operasi selain enflurane dan isoflurane. ${ }^{1}$ Paparan gas anestesi sevoflurane dan halothane dapat menyebabkan stres oksidatif akibat pelepasan radikal bebas dan produk peroksidasi lipid seperti malondialdehyde (MDA) ${ }^{5}$ dan juga peningkatan enzim terkait metabolisme radikal bebas seperti catalase, superoxide dismutase (SOD), glutathione peroxidase (GSH-Px), dan glutathione-s-transferase (GST). ${ }^{6}$

Inhalasi dengan sevoflurane dan isoflurane dalam banyak hal mempunyai efek farmakologi yang lebih baik bila dibanding dengan enflurane dan halothane. Demikian juga dalam hal efek samping, sevoflurane dan isoflurane mempunyai efek samping yang lebih minimal. Dengan alasan keamanan ini sevoflurane dan isoflurane lebih sering digunakan walaupun memakan biaya yang lebih tinggi. Halothane pada konsentrasi yang rendah $(<1 \%)$ tidak mengubah sensitivitas neuron terhadap glutamat, namun pada dosis yang lebih tinggi $(>1 \%)$ menyebabkan depresi sensitivitas neuron terhadap glutamate. Sevoflurane memiliki koefisien partisi gas darah yang rendah $(0,69)$ apabila dibanding dengan halothane. ${ }^{7,8}$

Negara kita yang beriklim tropis sangat kaya dengan bermacam tanaman yang berkhasiat bagi kesehatan manusia. Salah satunya adalah bayam merah atau Amaranthus tricolor linn. Bayam merah diketahui menjadi salah satu dari banyak sayuran yang kaya akan komponen antioksidan. ${ }^{9}$ Warna merah ini ditimbulkan oleh pigmen merah betalain (betaxanthine) yang ada pada daun dan batangnya. Bayam merah juga mengandung flavonoid, yaitu golongan polifenol yang juga memiliki properti antioksidan. Potensi antioksidannya jauh melampui seledri dan daun rosela. Umumnya bayam merah dikonsumsi 
dengan dimasak terlebih dahulu sehingga menyebabkan hilangnya komponen antioksidan di dalamnya. ${ }^{10}$

Penelitian ini bertujuan mengungkap efek pemberian bayam merah terhadap fungsi kognitif melalui petanda biologis (biomarker) neuroplastisitas otak yang terpapar anestesi inhalasi halothane dan sevoflurane. Keadaan ini penting untuk memelihara fungsi kognitif pascaanestesi dan keamanan pasien secara umum.

\section{Metode}

Penelitian ini adalah penelitian eksperimental laboratorik dengan mempergunakan rancangan randomized posttest only control group. Pemeliharaan hewan coba dilakukan di unit hewan coba Departemen Biokimia Fakultas Kedokteran Universitas Airlangga, sedangkan prosedur anestesi dilakukan di ruang operasi Rumah Sakit Hewan Fakultas Kedokteran Hewan Universitas Airlangga dan sudah dinyatakan laik etik dari Komisi Etik Penelitian Fakultas Kedokteran Hewan Universitas Airlangga (Unair) (Sertifikat No. 367-KE). Penelitian ini dilakukan periode Mei-Oktober 2014.

Unit eksperimen menggunakan tikus putih (Rattus norvegicus) galur Wistar jenis kelamin jantan, umur 1-1,5 bulan (sebelum pubertas), bobot kurang lebih 60-100 gram dengan kondisi sehat fisik. Jumlah subjek adalah 23 ekor yaitu 4 kelompok kontrol (K), 4 halothane (K1), 5 bayam merah dan halothane (K2), 5 sevoflurane (K3), serta 5 bayam merah dan sevoflurane (K4). Tikus dikelompokkan dalam kandang, diberikan makanan dan minuman secara ad libitum serta siklus terang gelap masing-masing 12 jam. Sebelum diberikan perlakuan, dilakukan proses aklimatisasi selama 2 minggu.

Pada prosedur anestesi, tikus ditempatkan di dalam kotak kaca dengan ukuran 30×25×25 $\mathrm{cm}$ yang terhubung dengan mesin anestesi AEONMED dengan vaporizer halothane dan juga sevoflurane dengan VP 300 (Beijing Aeonmed Co., Ltd.). Anestesi inhalasi halothane (dexa medica ${ }^{\circledR}$ ) dilakukan menggunakan dosis 1 MAC dengan dosis induksi 5\%, kemudian diturunkan menjadi $1 \%$ setelah refleks nyeri dan postur hilang. Pemberian paparan udara halothane dilakukan menggunakan alat vaporizer halothane dan sevoflurane dengan VP 300 (Beijing Aeonmed Co., Ltd.). Hal ini memungkinkan pengeluaran halothane dengan konsentrasi sesuai keinginan, pada suhu $20-35^{\circ} \mathrm{C}$, dengan kecepatan alir 2-10 L/menit. ${ }^{11}$ Pemberian anestesi dilakukan selama 60 menit. Pemberian sevoflurane (dexa medica ${ }^{\circledR}$ ) dilakukan memakai alat yang sama dengan dosis awal 5\% dan diturunkan menjadi $2,98 \%{ }^{11}$ setelah refleks nyeri dan postur hilang.

Ekstrak bayam merah diberikan dengan dosis $800 \mathrm{mg} / \mathrm{kgBB} /$ hari $^{12}$ pada pagi hari selama 7 hari. Daun segar dikeringkan dengan udara, dibuat menjadi bubuk, kemudian diekstraksi dengan etanol. Sebelum dipergunakan, ekstrak dilarutkan dengan CMC-Na. Suspensi bayam merah diberikan per sonde.

Dua puluh empat (24) jam pascaanestesi, dilakukan terminasi pada tikus dengan cara dekapitasi, lalu jaringan otak dipindahkan ke dalam tabung yang berisi paraformaldehid 10\% untuk selanjutnya dilakukan parafinisasi. Setiap subjek jaringan dibuat sediaan irisan dengan ketebalan $4 \mu \mathrm{m}$, kemudian menggunakan metode imunohistokimia terhadap ekspresi BDNF dan GLUR1 mempergunakan antibodi monoklonal terhadap protein BDNF dan GLUR1 (Bioss ${ }^{\circledR}$ ) dan kit imunohistokimia (Novocastra leica ${ }^{\circledR}$ ). Pemeriksaaan dan penghitungan ekspresi dengan menghitung jumlah sel yang reaktif (berwarna coklat) pada sel terhadap protein BDNF dan GLUR1pada area hipokampus pada 20 lapang pandang ${ }^{13}$ yang dimodifikasi dengan pembesaran 400x dipergunakan mikroskop Olympus CX21, kemudian diambil gambar berupa foto format JPEG dengan kamera Panasonic Lumix.

Data hasil penelitian ditabulasi dan dianalisis dengan memakai program SPSS 16.0 dengan uji statistik ANOVA. Apabila ditemukan perbedaan yang nyata antarkelompok maka dilanjutkan uji least significant difference (LSD) dengan tingkat kemaknaan $(\mathrm{p}<0,05)$.

\section{Hasil}

Bobot badan praperlakuan seperti terlihat pada Tabel 1 adalah homogen dan berdistribusinormal.

Tabel 1 Karakteristik Bobot Badan Hewan Coba Praperlakuan

\begin{tabular}{lccccccc}
\hline & $\begin{array}{c}\mathbf{K} \\
\mathbf{n = 4}\end{array}$ & $\begin{array}{c}\mathbf{K 1} \\
\mathbf{n = 4}\end{array}$ & $\begin{array}{c}\mathbf{K} \mathbf{n} \\
\mathbf{n}=\mathbf{5}\end{array}$ & $\begin{array}{c}\mathbf{K 3} \\
\mathbf{n = 5}\end{array}$ & $\begin{array}{c}\mathbf{K 4} \\
\mathbf{n = 5}\end{array}$ & $\mathbf{F}$ & $* \mathbf{p}$ \\
\hline $\begin{array}{l}\text { Bobot badan } \\
\text { (gram) }\end{array}$ & $87,50 \pm 4,65$ & $79,50 \pm 6,81$ & $78,60 \pm 5,46$ & $85,80 \pm 5,36$ & $78,80 \pm 6,87$ & 2,348 & 0,093 \\
\hline
\end{tabular}

Keterangan: data adalah X \pm SD. *ANOVA dan LSD 
Raden Argarini: Pemberian Ekstrak Bayam Merah (Amarantus Tricolor linn) Memperbaiki Ekspresi BDNF dan GLUR1

Tabel 2 Ekpresi BDNF pada Area Hipokampus

\begin{tabular}{|c|c|c|c|c|c|c|c|}
\hline & $\underset{n=4}{K}$ & $\begin{array}{c}K 1 \\
n=4\end{array}$ & $\begin{array}{r}\mathrm{K} 2 \\
\mathrm{n}=5\end{array}$ & $\begin{array}{c}\mathrm{K} 3 \\
\mathrm{n}=5\end{array}$ & $\begin{array}{c}\mathrm{K} 4 \\
\mathrm{n}=5\end{array}$ & $\mathbf{F}$ & $* \mathbf{p}$ \\
\hline BDNF & $5,00 \pm 1,41$ & $4,00 \pm 1,41^{\mathrm{a}}$ & $14,80 \pm 3,20^{\mathrm{b}}$ & $3,60 \pm 0,89^{c}$ & $15,40 \pm 2,51^{b}$ & 37,83 & 0,000 \\
\hline
\end{tabular}

Berdasarkan uji homogenitas varian didapatkan nilai $\mathrm{p}=0,916(\mathrm{p}>0,05)$ dan hasil tes 1 -sampel $\mathrm{KS}$ $\mathrm{p}=0,697$ ( $\mathrm{p}>0,05)$. Pada saat pemberian bayam merah maupun plasebo terdapat 2 hewan yang mati, yaitu pada kelompok kontrol (-) dan halothane (K1)

Espresi BDNF dapat dilihat pada Tabel 2 dan Gambar 1, terlihat bahwa pemberian gas anestesi halothane dan sevoflurane menurunkan ekspresi BDNF pada area hipokampus. Pada kelompok dengan pemberian bayam merah, ekspresi BDNF lebih tinggi dibanding dengan kelompok kontrol dan kelompok yang diberikan halothane serta sevoflurane saja.

Ekspresi GLUR1 dapat dilihat pada Tabel 3 dan Gambar 3, terlihat bahwa ekspresi GLUR1 lebih tinggi pada kelompok pemberian gas anestesi halothane dan sevoflurane pada area hipokampus. Pada kelompok dengan pemberian bayam merah, ekspresi GLUR1 menjadi lebih rendah bila dibanding dengan kelompok kontrol serta kelompok yang diberikan halothane dan sevoflurane saja.

\section{Pembahasan}

Anestesi umum kini diketahui sebagai salah satu zat agen yang memiliki potensi kerusakan atau gangguan performa kognitif pada usia yang ekstrem, yaitu terlalu muda atau terlalu tua. Sejumlah penelitian preklinik dan studi retrospektif menyatakan bahwa anestesi umum dapat menyebabkan gangguan perkembangan pada usia muda terutama pada proses belajar dan memori, serta kemungkinan juga mempercepat proses penurunan kognitif pada usia lanjut.
Namun, data klinis yang ada hingga kini masih kurang dipahami. ${ }^{14}$

Terdapat 2 faktor penting yang menentukan neurotoksisitas anestesi, yaitu pada tahapan perkembangan otak pada saat terpapar dan derajat paparan gas anestesi yang meliputi frekuensi paparan dan dosis anestesi kumulatif. Faktor lain yang berpengaruh adalah gas anestesi lain yang dipergunakan, status kesehatan, dan prosedur spesifik lainnya. ${ }^{14}$ Pada hasil penelitian ini dapat dilihat bahwa terdapat penurunan ekspresi BDNF pada kelompok yang diberikan halothane dan sevoflurane terhadap kelompok kontrol serta peningkatan ekspresi GLUR1 pada hipokampus tikus yang terpapar halothane dan sevoflurane dibanding dengan kelompok kontrol.

Pada hewan rodensia dewasa, paparan antagonis reseptor glutamat pada tipe NMDA atau modulator positif reseptor GABA dapat meningkatkan apoptosis. Terdapat bukti bahwa semakin sering menggunakan anestesi umum dapat menyebabkan neurodegenerasi pada neonatal. Keadaan ini dibuktikan pada studi yang dirancang untuk model anak, paparan zat anestesi diberikan pada bayi tikus pascakelahiran (P7) yang diberikan gabungan isoflurane dan midazolam serta nitrous oxide dengan dosis yang cukup untuk mempertahankan operasi selama enam jam. Segera setelah paparan, anak tikus mengalami apoptosis neuronal berlebihan pada seluruh otak, termasuk hipokampus dan korteks otak. Efek apoptosis ini adalah signifikan baik fisiologis, dengan penurunan potensiasi jangka panjang hipokampus (model in vitro plastisitas sinaptik yang relevan untuk belajar dan memori). Secara perilaku terdapat gangguan memori spasial setelah remaja yang menetap

Tabel 3 Ekpresi GLUR1 pada Area Hipokampus

\begin{tabular}{|c|c|c|c|c|c|c|c|}
\hline & $\begin{array}{l}K \\
n=4\end{array}$ & $\begin{array}{l}K 1 \\
n=4\end{array}$ & $\begin{array}{c}\mathrm{K} 2 \\
\mathrm{n}=5\end{array}$ & $\begin{array}{l}\mathrm{K} 3 \\
\mathrm{n}=5\end{array}$ & $\begin{array}{l}\mathrm{K} 4 \\
\mathrm{n}=5\end{array}$ & $\mathbf{F}$ & $* \mathbf{p}$ \\
\hline GLUR1 & $3,00 \pm 0,82$ & $14,25 \pm 2,22^{\mathrm{a}}$ & $3,20 \pm 1,30$ & $13,80 \pm 2,49^{b}$ & $5,00 \pm 0,71$ & 52,156 & 0,000 \\
\hline
\end{tabular}

Keterangan: $\mathrm{a}=\mathrm{p}<0,05$ dari kelompok kontrol, $\mathrm{BM}+$ halothane, sevoflurane, $\mathrm{BM}+$ sevoflurane (lebih tinggi). $\mathrm{b}=\mathrm{p}<0,05$ dari

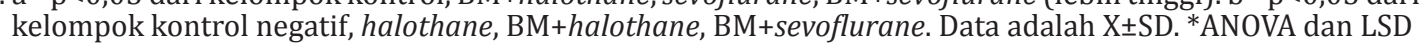




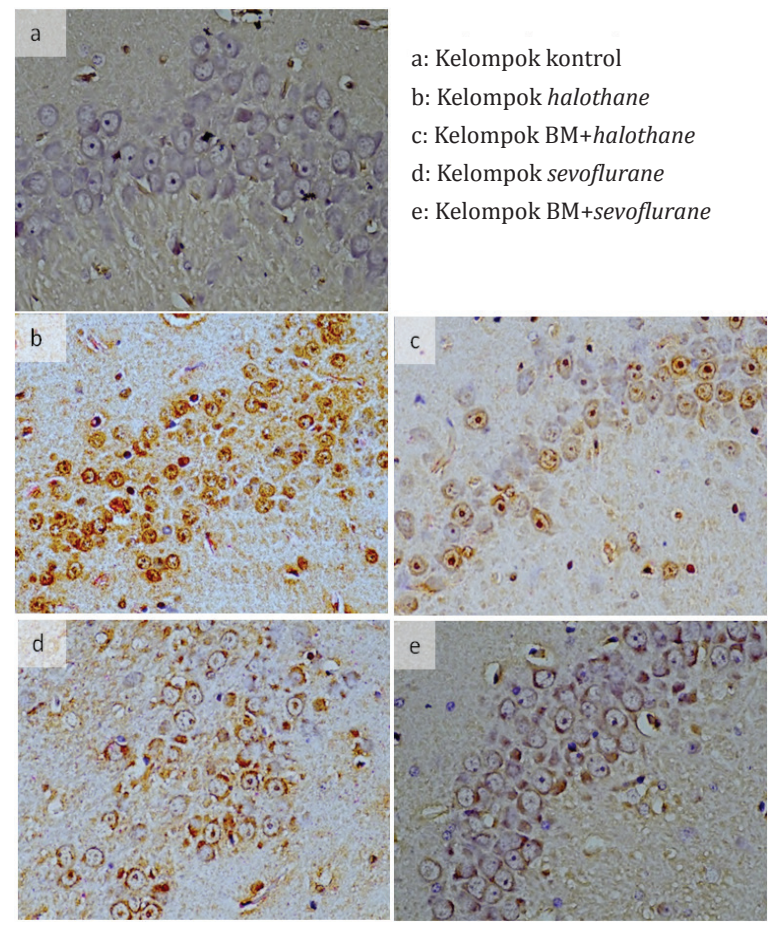

Gambar 1 Perbandingan Sel yang Positif Mengekspresikan BDNF pada area Hipokampus

Sel yang reaktif (berwarna coklat) pada sel terhadap protein BDNF. Pembesaran $400 x$

hingga dewasa. Paparan terhadap isoflurane (zat anestesi tunggal) saja menyebabkan apoptosis yang signifikan sehingga penambahan agen lain sebagai campuran secara substansial lebih meningkatkan tingkat apoptosis. Paparan tikus neonatal terhadap desflurane, isoflurane, dan sevoflurane menghasilkan peningkatan serupa dalam apoptosis sel. Secara kolektif, penelitianpenelitian ini telah menggambarkan pentingnya eksperimental yang lebih rinci seperti dosis, durasi, waktu, dan spesies, serta hasil belajar. Penekanan anestesi pada aktivitas neuronal spontan dapat mengakibatkan sekresi faktor neurotropik tidak cukup seperti BDNF pada perkembangan sistem saraf. ${ }^{14}$

Faktor pertumbuhan otak pada umumnya, dan BDNF pada khususnya kemungkinan besar berperan pada gangguan kognitif pascaanestesi. Penelitian menggunakan isoflurane dan propofol terdapat penurunan yang nyata pada spina dendrit. Hal ini bersamaan dengan aktivasi RhoA dan faktor reseptor $\mathrm{p} 75^{\mathrm{NTR}}$ sebagai bagian jalur kaskade yang dapat menganggu depolimerasi aktin pada mikrotubul dan juga selanjutnya transport akson. Gangguan pada mikrotubul ini
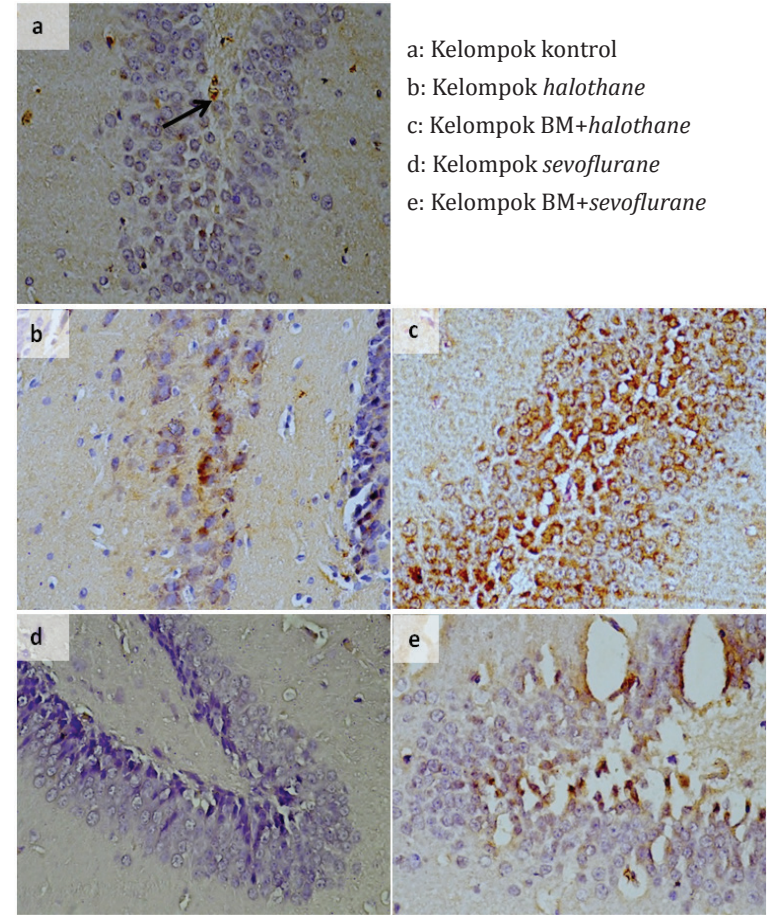

\section{Gambar 2 Perbandingan Ekpresi GLUR1 pada Area Hipokampus.}

Sel yang reaktif (berwarna coklat) pada sel terhadap protein GLUR1. Pembesaran $400 \mathrm{x}$

menyebabkan gangguan proses transpor BDNF. ${ }^{15}$

BDNF ini berperan sebagai modulator pada platisitas sinaps di area hipokampus. Terdapat inhibisi atau gen $B D N F$ yang berkurang akan menyebabkan defisiensi long-term potentiation (LTP) yang berperan pada perubahan memori jangka pendek menjadi jangka panjang. Defisiensi fungsi sinaps ini dapat diperbaiki dengan aplikasi eksogen atau overekspresi BDNF. ${ }^{16}$

Untuk pembentukan memori jangka panjang dari memori jangka pendek diperlukan proses yang dinamakan long term potentiation. Efek yang penting aktivasi reseptor muskarinik adalah fasilitasi LTP sehingga terjadi plastisitas sinaps pada neuron hipokampus dan neokorteks. Pada membran presinaps, reseptor nikotinik (nAchRs) akan meningkatkan pelepasan glutamat. Aktivasi kolinergik pada korteks serebri berkontribusi terhadap konsolidasi memori pada suatu pengalaman yang merupakan stimulus dan juga bersifat emosional. ${ }^{16}$ Anestesi umum mempunyai target terutama pada kanal ion bergantung pada neurotransmiter, terutama pada reseptor $\delta$-Aminobutyric acid (GABA), glutamate serta $N$-methyl $D$-aspartate pada celah sinaps dan 
ekstrasinaps. ${ }^{3}$ GLUR1 yang merupakan reseptor tipe 1 dari glutamat terlihat akan mengalami upregulation sebagai mekanisme kompensasi dari kadar glutamat yang rendah sehingga mencegah apoptosis yang berlebihan pada sel neuron.

Setelah pemberian ekstrak bayam merah dengan dosis $800 \mathrm{mg} / \mathrm{kgBB}$ selama tujuh hari sebelum dipaparkan dengan gas anestesi, pada hasil dapat dilihat bahwa terdapat perbaikan ekspresi BDNF dan GLUR1 mendekati atau menuju ke normal. Pada bayam merah selain mengandung provitamin A (b karotene) juga mengandung mineral seperti kalsium dan juga besi, serta sumber skualen. ${ }^{12}$ Bayam merah mempunyai kandungan $\beta$-karoten, folat, vitamin $\mathrm{C}$ (asam askorbat), pigmen betacianin amaranthin dan isoamaranthin yang memiliki peran sebagai antioksidan. ${ }^{17}$ Kandungan antioksidan tersebut dapat mencegah stres oksidatif terutama proses peroksidasi lipid yang ditimbulkan oleh paparan gas anestesi. Selain itu, kandungan folat pada bayam merah dapat meningkatkan neurogenesis pada hipokampus. ${ }^{5,6}$ Folat dapat meningkatkan proliferasi sel dan ekspresi Notch1 dan Hes 1 serta penurunan Mash 1 pada stem sel saraf. Selain itu, folat juga dapat mengaktifkan notch signaling. ${ }^{18}$ Defisiensi folat akan menimbulkan level homosistein yang dapat mengganggu sistem metabolisme monoamine pada otak sehingga terjadi gangguan pada proses neurogenesis girus dentatus hipokampus. ${ }^{19,20}$ Dengan demikian, pemberian jus bayam merah yang kaya akan folat dan antioksidan memungkinkan terjadinya peningkatan neurogenesis dan juga daya tahan neuron, ditandai dengan perbedaan ekspresi BDNF area hipokampus pada kelompok terpapar anestesi (halothane dan sevoflurane) dengan kelompok kontrol dan kelompok yang diberikan perlakuan bayam merah.

Penelitian lebih lanjut diperlukan dalam hal mekanisme stres oksidatif akibat gas anestesi maupun prosedur pemberiannya serta dosis optimal pemberian bayam merah. Simpulan, gas anestesi halothane dan sevoflurane dapat mengganggu homeostatis BDNF dan reseptor glutamat pada area hipokampus. Pemberian bayam merah juga dapat memperbaiki ekspresi BDNF dan GLUR1, yaitu protein yang terkait dengan fungsi kognitif dan neuroplastisitas otak sehingga mempunyai potensi untuk mencegah neurotoksisitas pada fungsi kognitif.

\section{Ucapan Terima Kasih}

Kami mengucapkan terimakasih yang sebesar- besarnya kepada Direktorat Pendidikan Tinggi yang telah mendanai penelitian ini melalui program riset hibah unggulan.

\section{Daftar Pustaka}

1. Morgan GJ, Mikhail M, Murray M. Inhalational Anesthetic. Dalam: Morgan GE, Mikhail MS, Murray MJ, penyunting. Clinical snesthesiology. Edisi ke-4. New York: Lange Medical Books/McGraw- Hill; 2006. hlm. 155-78.

2. Loepke AW, Soriano SG. An assessment of the effects of general anesthetics on developing brain structure and neurocognitive function. Pediatr Anesthesiol. 2008;106(6):1681707.

3. Hudson A, Hemming Jr H. Are anaesthetics toxic to the brain?. Br J Anaesth. 2011; 107(1):30-7.

4. Lujan R, Shigemoto R, Lopez-Bendito G. Glutamate and GABA receptor signaling in the developing brain. Neuroscience. 2005;130:567-80.

5. Arnaotoglou H, Vretzakis G, Souliotis D, Cambili M, Galaris D, Papadopoulos G. The effects of propofol or sevoflurane on free radical production after tourniquet induced ischaemia-reperfusion injury during knee arthroplasty. Acta Anaesth Belg. 2007;58:36.

6. Dikmen B, Unal Y, Pampal HK, Nurlu N, Kurtipek 0, Canbolat 0, dkk. Effects of repeated desflurane and sevoflurane anesthesia on enzymatic free radical scavanger system. Mol Cell Biochem. 2007; 294:31-6.

7. Austin V, Blamire A, Allers K, Sharp T. Confounding effects of anesthesia on functional activation in rodent brain: a study of halothane and $\alpha$-chloralose anesthesia. Neuroimage. 2005;24:92-100.

8. Rörtgen D, Kloos J, Fries M, Grootke O, Rex S, Rossaint R, dkk. Comparison of early cognitive function and recovery after desflurane or sevoflurane anaesthesia in the elderly: a double-blinded randomized controlled trial. Br J Anaesth. 2010;104(2):167-74.

9. Amin I, Norazaidah Y, Hainida K. Antioxidant activity and phenolic content of raw and blanched Amaranthus species. Food Chem [Online journal]. 2006 [diunduh 28 Agustus 2014]. Tersedia dari: http://www. sciencedirect.com/science/article/pii/ S0308814604008088 
10. Wong S, Leong L, Koh J. Antioxidant activities of aqueous extracts of selected plants. Food Chem. 2005;99(4):775-83.

11. Barbry T, Le Guen M, De Castro V, Coriat P, Riou B, Vivien B. Minimum alveolar concentration of halogenated volatile anaesthetics in left ventricular hypertrophy and congestive heart failure in rats. Br J Anaesth. 2007;99(6):787-93.

12. Krishna A, Kumar A. Evaluation of radioprotective effects of Rajgira (Amaranthus paniculatus) extract in Swiss albino mice. J Radiat Res. 2005;46(2):233-9.

13. Nair-Roberts R, Chatelain-Badie S, Benson E, White-Cooper H, Bolam J, Ungless M. Stereological estimates of dopaminergic, GABAergic and glutamatergic neurons in the ventral tegmental area, substantia nigra and retrorubral field in the rat. Neuroscience. 2008;152(4):1024-31.

14. Todorovic V, Absalom AR, Blomgren K, Brambrink A, Crosby G, Culley DJ, dkk. Anaesthetic neurotoxicity and neuroplasticity: an expert group report and statement based on the BJA Salzburg Seminar. Br J Anaesth. 2013;111(2):143-51.

15. Head BP, Patel HH, Niesman IR, Drummond
JC, Roth DM, Patel PM. Inhibition of p75 neurotrophin receptor attenuates isofluranemediated neuronal apoptosis in the neonatal central nervous system. Anesthesiology. 2009;110(4):813-25.

16. Bennaroch E. Application, basic neurosciences with clinical application. Philadelphia: Elsevier; 2006.

17. Cai Y, Sun M, Corke H. Characterization and application of betalain pigments from plants of the Amaranthaceae. Trends Food Sci Technol. 2005;16(9):370-6.

18. Zhang $\mathrm{X}$, Huang G, Liu H. Folic acid enhances notch signaling, hippocampal neurogenesis, and cognitive function in a rat model of cerebral ischemia. Nutr Neurosci. 2012;15(2):55-61.

19. Kronenberg G, Harms C, Sobol R, Cardozo PF, $\mathrm{H}$ L, Winter B, dkk. Folate deficiency induces neurodegeneration and brain dysfunction in mice lacking uracil DNA. J Neurosci. 2008;28(28):7219-30.

20. Kruman I, Mouton P, Emokpae Jr R, Cutler R, Matsson M. Folate deficiency inhibits proliferation of adult hippocampal progenitors. Neuroreport. 2005;16(10): 1055-9. 